\title{
Determination of the Perceptions of Sport Managers on the Concept of Organization: A Metaphor Analysis Study
}

\author{
Serkan Kurtipek ${ }^{1}$, Nuri Berk Gungor ${ }^{1}$ \\ ${ }^{1}$ Faculty of Sports Sciences, Gazi University, Ankara, Turkey \\ Correspondence: Serkan Kurtipek, Faculty of Sports Sciences, Gazi University, Ankara, Turkey.
}

Received: December 3, 2018

Accepted: December 26, 2018

Online Published: January 3, 2019

doi:10.11114/jets.v7i2.3934

URL: https://doi.org/10.11114/jets.v7i2.3934

\begin{abstract}
This research aims to determine the perceptions of sports managers on the concept of organization with the help of metaphors. The sample of study consists of 45 sports managers. In order to collect data in the study, "metaphor form" was prepared to determine the perceptions of the sport managers on the concept of organization. In the metaphor form, the sport managers were asked to complete the sentence "Organization is like.....; because........". In the study, phenomenological design, one of the from qualitative research approaches was used. In the analysis of the data, content analysis technique was used. The reliability coefficient for the inter-participants was calculated for the reliability of the analysis of the research data and this value was found to be $91 \%$. With the evaluation of the data, it was seen that sport managers produced a total of 34 metaphors. These metaphors were collected in 4 different categories. These are respectively "being systematic", "management", "purpose" and "division of labor". The most produced metaphors by sports managers are family, car, human body, and puzzle. Living, lifeless, abstract and concrete metaphors were generally used for the concept of organization.
\end{abstract}

Keywords: sports, sport manager, metaphor, qualitative research method

\section{Introduction}

Sport is undoubtedly one of the most common social activities of modern societies (Yetim, 2005). In time, it emerged as a social quality and increased its importance every day (Kurt, 1997). Sport has become an important service sector with its protective and developing qualities that protect personal and social health. In addition, the sport, which has become a profitable advertising and promotion tool with the influence of the mass communication and the media in particular, transformed into a consumption sector as a show and entertainment activity that attracted the attention of large masses, while on the other hand it became an attractive economic activity with significant financial movements for entrepreneurs (Can \& Soyer, 2000).

Since the sport now becomes a professional and a big industry, and investments in this industry have exceeded the size of being limited to only clubs and athletes. The entertainment sector, the media sector, the mutual betting sector, the sports goods sector, the transport sector and the tourism sector monitor and utilize the developments directly and indirectly the sports industry. Again, many media organizations in the world have become interested in the sports industry (Dpt, 2000). With the increasing interest in sports and sports stakeholders, the quality of sports organizations has become one of the parameters to be improved.

Sport organizations are becoming more and more complex and difficult to be liked, showing parallelism with the technical and technological conditions of today's world. Therefore, stronger specialization, division of labor, and coordination have become mandatory (Erkal, Güven \& Ayan, 1998). The fact that each sport organizations has different characteristics and time, facilities, responsible people and competitors, and weather conditions differ each time show that organizational activity requires a high level of effort and expertise (Balc1, 1999). It is also important to note that a coordinated teamwork is needed for the successful implementation of organizations.

The globalization of sport in time, the reaching of large masses in the societies, increasing in its level of influence and diversity have increased the importance of the management of sport elements. The fact that national and international sportive activities reach more and more people every day has raised the issue of how to improve the quality of these activities. How sportive activities are organized is of particular importance at this point. Efficient and effective implementation of the organization activities in this process will increase the quality. For this reason, it was the starting 
point of this research to determine to what extent the sports managers managing these activities care these organization of sportive activities, what they liken the organization to and what they associate the organization with, through metaphors.

The concept of metaphor is the art of expressing with less word and in a more stressed way and using words beyond their true meaning. It is also defined as metonymy. Metaphor, in other words, figure of speech, is figuratively the transfer or reflection of social reality. This situation is also called metaphoric or metaphorical narration (Balc1, 2008). With metaphor, people connect new information to their old information by pasting them into the already existing schema in their minds. In this way, metaphors establish strong links between people's past learning and personal experiences and newly learned concepts. When the international literature is examined, it is seen that there are studies on organization and metaphors (Bies, 1996; Melao \& Pidd, 2000; Boje, Luhman \& Cunliffe, 2003; Eijnatten, 2004; Cornelissen, 2006; Eruzun, Kınalı \& Erturan, 2017; Cornelissen, Holt \& Zundel, 2011; Miller, 2008). When the national literature is examined, there is no study that tries to explain the concept of organization through metaphor. However, there are studies on the concepts of organization, management, leadership and manager (Öztel \& Hinz, 2001; Tamimi, 2005; Uzun \& Erdem, 2017; Kurtipek, Çelik, Gümüş \& Yılmaz, 2017). In this study, it was aimed to determine the perceptions of sports managers on the concept of organization with the help of metaphors.

\section{Material and Methods}

In this study, phenomenological design, one of the qualitative research methods, was selected. The sample of this study conducted in 2018 consists of 45 sports manager in Turkey. The study group was chosen by criterion sampling method according to purposeful sampling method. In this context, criteria such as managers working at various levels in the Ministry of Youth and Sports, presidents of independent sports federations and managers wanting to participate voluntarily were taken into consideration. In this study, data were collected using semi-structured interview form which is very frequently used in metaphor research (Döş, 2010; Inbar, 1996; Saban, 2009). At this point, sport managers were asked to state a metaphor describing the organization and explain these metaphors. The participants were asked to complete the sentence of "Organization is like.....; because......", and as a result, it was determined that the participants indicated a single metaphor and explained these metaphors.

In the analysis of the data, firstly, the papers were given numbers from 1 to 45 . The data were analyzed by content analysis method in the study. Content analysis is the categorization of data (Patton, 2014).

Content analysis was conducted in 8 stages. These are (1) examination of forms and elimination of inappropriate forms; (2) recompilation of forms, (3) numbering of forms (4) examination of metaphors, (5) development of categories, (6) ensuring validity and reliability (7) calculation of frequencies, and (8) interpretation (Saban, 2008; Ekici, Gökmen \& Kurt, 2014; Ekici, 2016).

In the first stage, the participants' expressions were investigated and whether there were any blank parts or not was examined in general and there was no form with missing part. In the stage of recompilation of forms, the metaphors in the forms were listed and tabulated. In the stage of numbering of forms, the numbering from P1 to P50 was made after organizing the metaphors according to their frequency. In the stage of development of categories, metaphors for the concept of manager were examined in terms of their common features. As the metaphors stated by the participants were emphasized in a way that they could be included in several categories at the same time, the metaphors were placed in the relevant categories according to the participants' statements.

In the stage of validity and reliability, the process of analyzing the data obtained from the participants and how the codes associated with the categories were directly presented to the reader with the participants' statements. In the research, samples of participant views were selected and included in the findings section (Yıldırım \& Şimşek, 2014). In order to ensure the reliability of the study, data were analyzed by 3 field experts and the results of the analysis were compared. In the reliability of data analysis, the formula developed by Miles and Huberman in 1994 was used (Miles \& Huberman, 1994). A total of 34 metaphors were produced and 3 metaphors were identified. The mean reliability of the encoders was found to be $94 \%[31 /(31+3) \times 100=91 \%]$. According to these results, the research has the desired reliability level.

\section{Findings}

This section includes metaphors developed by sports managers on the concept of organization, evaluation of these metaphors under relevant categories and the description examples. 
Table 1: Metaphors Developed by Sport Managers for Organization Concept

\begin{tabular}{|c|c|c|c|c|c|}
\hline Metaphor Order & Metaphor Name & $\mathbf{f}$ & Metaphor Order & Metaphor Name & $\mathbf{f}$ \\
\hline 1 & Family & 4 & 19 & Management & 1 \\
\hline 2 & Car & 3 & 20 & Sports Activity Show & 1 \\
\hline 3 & Human Body & 3 & 21 & Olympiad & 1 \\
\hline 4 & Puzzle & 2 & 22 & Festival & 1 \\
\hline 5 & Game & 2 & 23 & Raising a Baby & 1 \\
\hline 6 & World & 2 & 24 & Dessert & 1 \\
\hline 7 & Operation of the Machine & 2 & 25 & Training & 1 \\
\hline 8 & Taekwondo & 1 & 26 & Institution & 1 \\
\hline 9 & Space & 1 & 27 & Cheetah & 1 \\
\hline 10 & Business & 1 & 28 & Team & 1 \\
\hline 11 & Life & 1 & 29 & Father & 1 \\
\hline 12 & Leadership & 1 & 30 & Chain & 1 \\
\hline 13 & Mother & 1 & 31 & Teamwork & 1 \\
\hline 14 & State & 1 & 32 & Pyramid & 1 \\
\hline 15 & Design & 1 & 33 & Honey Hive & 1 \\
\hline 16 & Team Success & 1 & 34 & Ants & 1 \\
\hline 17 & The bearer & 1 & & & \\
\hline 18 & Planning & 1 & & TOTAL OPINION & 45 \\
\hline
\end{tabular}

When Table 1 is examined, it is seen that sport managers produced 34 types of metaphors for the concept of "Organization" and stated 45 opinions for this. Metaphors of family (4), car (3) and human body (3) were the most frequently metaphors. Participants made analogies to concrete and abstract expressions (state, design, dessert, chain, etc.) and to living things (cheetah, ants, etc.) in order to explain the concept of organization.

By taking into account the descriptions/justifications of the metaphors developed by the participants on the concept of organization, Table 2 presents the classification of metaphors in terms of common characteristics.

Table 2. Distribution of Metaphors Developed by Sports Managers according to Categories

\begin{tabular}{lcc}
\hline Categories & Number of Metaphors (f) & $\%$ \\
\hline 1. Being Systematic & 9 & 26.47 \\
\hline 2. Management & 9 & 26.47 \\
\hline 3. Purpose & 8 & 23.52 \\
\hline 4. Division of Labor & 8 & 23.52 \\
\hline TOTAL & $\mathbf{3 4}$ & $\mathbf{1 0 0 . 0}$ \\
\hline
\end{tabular}

According to Table 2, metaphors developed by sport managers for the concept of organization are grouped under four categories. These are Being Systematic (9- 26.47\%), Management (9- 26.47\%), Purpose (8-\% 23.52), and Division of Labor (8-\% 23.52).

From Table 3 to Table 6, metaphors in the specified categories and the description examples for the metaphors are included.

Table 3. Metaphors in "Being Systematic" category and Description Examples

Category Number of Metaphors $(f=9)$

1.Being
Systematic

Quotations from the description examples of sports managers;

Puzzle; Each of its piece has a great importance. If one piece is missing, it cannot be completed (P7)

Car; The car runs in a certain order. Each part has a separate task. Lack of a part affects others (P9)

Space; It hosts all systems. It is a perfect organization in summer and winter, day and night (P10)

World; The world is an organization that covers everything and includes certain systems (P11)

As seen in Table 3, 9 metaphors are mentioned in the "Being Systematic" category on the concept of organization. As it is understood from the examples in the description statements given for metaphors; stating that it is similar puzzle, each piece has a great importance, cannot be completed if one piece is missing and so on, participants emphasized that it is within the organization system. 
Table 4. Metaphors in "Management" category and Description Examples

\begin{tabular}{ll}
\hline Category & Number of Metaphors (f=9) \\
\hline \multirow{2}{*}{ 2.Management } & Leadership (1), Mother (1), State (1), Design (1), Team Success (1), The bearer (1), Planning (1), \\
& Managent (1), Sports activity show (1)
\end{tabular}

Quotations from the description examples of sports managers;

Mother; She plans, implements and manages everything (P17)

State; It does everything necessary to manage a country (P19)

Management; You need to manage people and businesses. This is important to achieve the goal (P25)

As shown in Table 4, a total of 9 metaphors for the concept of organization are stated in the "Management" category. As it is understood from the examples in the description statements given for metaphors, it is seen that the participants emphasized the direct relationship of the organization with the management.

Table 5. Metaphors in "Purpose" category and Description Examples

\begin{tabular}{lc}
\hline Category & Number of Metaphors (f=8) \\
\hline 3.Purpose & Olympiad (1), Festival (1), Raising a Baby (1), Dessert (1), Training (1), Institution (1), Cheetah (1), Team
\end{tabular}

Quotations from the description examples of sports managers;

Olympiad; People come together for a specific purpose (P27)

Festival; It is done in unity for a purpose (P28)

Training; It has a certain purpose, just like the organization (P33)

Institution; It is established and managed for a purpose (P34)

As seen in Table 5, a total of 8 metaphors are specified in the "Purpose" category on the concept of organization. As it is understood from the examples in description statements given for each metaphor, it is seen that the participants emphasize that every organization carried out has a purpose by specifying the statements such as it has a certain purpose like training, it is carried out for a purpose like festival etc..

Table 6. Metaphors in "Division of Labor" category and Description Examples

\begin{tabular}{lc}
\hline Category & Number of Metaphors (f=8) \\
\hline 4. Division of Labor & Family (4), Father (1), Chain (1), Teamwork (1), Operation of Machine (2), Pyramid (1), \\
& Honey Hive (1), Ants (1) \\
\hline
\end{tabular}

Quotations from the description examples of sports managers;

Family; All members of the family have separate tasks to perform (P41)

Pyramid; In order to achieve the purpose of the system, a variety of division of labor must be done. Each work is linked to the other (P43)

Honey Hive; Every bee is busy with something. There are bees responsible for many activities such as cleaning, care, nursing, honey production, hive repair (P44)

Ants; They are organized and all have a task (P45)

As seen in Table 6, a total of 8 metaphors are specified in the "Division of Labor" category on the concept of organization. As it is understood from the examples in description statements given for each metaphor, it is seen that participants have emphasized the need for the division of labor in order to be successful in the organizations and to reach the goal as soon as possible by using the expressions such as every bee is busy with something. There are bees responsible for many activities such as cleaning, care, nursing, honey production, hive repair.

\section{Discussion and Conclusion}

In this research, it was aimed to determine the emotions and thoughts of sports managers on the concept of organization by analogy. According to the results, the perceptions of the participants on the concept of organization were interpreted.

It was concluded that the participants produced a total of 34 metaphors on the concept of organization. Metaphors produced are grouped in 4 different categories. These are the categories of being systematic, management, purpose and 
division of labor. A total of 9 metaphors were specified in the category of "Being Systematic". With the expressions of these metaphors such as; it is like puzzle, each of its piece has a great importance, if one piece is missing, it cannot be completed, it is like space, it hosts all systems. It is a perfect organization in summer and winter, day and night, it is like car, the car runs in a certain order, each part has a separate task, lack of a part affects others; it is seen that participants emphasize the importance of the planned and regular action for the organizations within a system. When the literature is examined, it is seen that metaphors were produced that emphasize the importance of being systematic with different expressions (Bloom, Castagna \& Warren, 2003; Dönmez, 2008; Kösterelioğlu, 2014).

The other category in which the participants have an equivalent opinion with respect to "being systematic" for the concept of organization is the "Management" category. A total of 9 metaphors were stated in the related category. These metaphors consist of expressions such as; it is like management, You need to manage people and businesses, this is important to achieve the goal, it is like state, It does everything necessary to manage a country, it is like mother, She plans, implements and manages everything. Relevant expressions refer to the relationship between organization and management. Management is the sum of efforts to direct a group of people to defined goals, to provide a division of labor, cooperation and coordination between them (Eren, 2008). It helps to understand the future as much as to create and establish the future of the organization's competitor (Fahey \& Randall, 1994). In order to achieve the goals set, the act of management must be carried out in a healthy manner. Reviewing the literature, there are studies that emphasize the importance of management skills of managers, which supports the results of the study (Dönmez, 2008; Monroe, 2003; Browne-Ferrigno, 2003; Aydoğdu, 2008). And also, In effective management, good corporate communication skills are also important (Üzüm, Söznmezoğlu, Karlı \& Yıldız, 2015; Yıldız, 2016).

According to the results of the study, another category produced is gathered under the title of "Purpose". A total of 8 metaphors were developed in this category. Metaphors produced by the participants are; it is like Olympiad, people come together for a specific purpose, it is like festival, it is done in unity for a purpose, it is like institution, it is established and managed for a purpose, it is like training, it has a certain purpose, just like the organization. Each activity starts first with a careful planning (Dönmez, 2008). Each planning is intended to achieve the goal that the activities are intended to achieve or reach. There is no plan and activity with no purpose. Purposes are the most important elements for the establishment of the organization and the organization reason of the activities. Knowing the purposes means eliminating uncertainties. In this way, the staff will be able to act by making sure what to do and where to go at the moment and in the future. In this context, when the "purpose" metaphor is considered, the organization to be realized should have a purpose or purposes in a certain framework. Otherwise, it is not possible to talk about organization action. Morover, it is stated that goal setting has a positive effect on the determined target (Yurdakul, 2015).

The last category that the participants produced for the concept of organization is the "division of labor". A total of 8 metaphors were produced in the category of "division of labor". In this category, with the expressions such as it is like family, all members of the family have separate tasks to perform, it is like ants, they are organized and all have a task, it is like pyramid, sin order to achieve the purpose of the system, a variety of division of labor must be done, it is understood that the participants emphasized the importance of the division of labor for organizations. All staff assigned to perform the objectives of the organizations planned in line with the targets set must take responsibility in a coordinated manner. The lack of a link in the ring of the chain could have an effect that could overshadow the success of an entire organization. For this reason, the people responsible for the organization management should perform the division of labor carefully. Also, it was determined that correctly planned activities with a division of labor reduced the costs in the long term and paved the way for effective use of employment (Taş, 2016).

As a result, the participants tried to explain the concept of organization with the metaphors they produced from a different perspective. In the light of the data obtained, the participants stated that the concept of organization has a complex structure rather than a simple structure, that it contains the elements that should be considered in its own structure and that the stones connected with a chain effect form the structure. In addition, it is possible to state that the organizations are the structures that carry out their activities in accordance with the specific purpose and that have a systematic division of labor and that have a comprehensive management activity power. 


\section{References}

Aydoğdu, E. (2008). Analysis of school perceptions of students and teachers in primary schools and their ideal school perceptions through metaphors. Unpublished master's thesis. Osmangazi University, Eskişehir.

Balc1, A. (Ed.) (2008). Organization metaphors. Ankara: Ekinoks.

Balc1, V. (1999). Sports Activities Planning and Management, Ankara: Bağırgan Publisher.

Bies, W. (1996). Thinking with the help of images: On the metaphors of knowledge organization. Knowledge organization, 23(1), 3-8. https://doi.org/10.5771/0943-7444-1996-1-3

Bloom, G., Castagna, C., \& Warren, B. (2003). More than mentors: Principal coaehing. Leadership, May/ June, $20-23$.

Boje, D. M., Luhman, J. T., \& Cunliffe, A. L. (2003). A dialectic perspective on the organization theatre metaphor. American Communication Journal, 6(2), 1-16.

Browne-Ferrigno, T. (2003). Becoming a principal: Role conception, initial socialization, roleidentity transformation, purposeful engagement. Educational Administration Quarterly, 39(4), 468-503. https://doi.org/10.1177/0013161X03255561

Can, Y., \& Soyer, F. (2000) Evaluation of Factors Affecting Efficiency in Sport Services, 1st Gazi Physical Education and Sport Sciences Congress, 2, 182-200, Ankara.

Cornelissen, J. P. (2006). Metaphor and the dynamics of knowledge in organization theory: A case study of the organizational identity metaphor. Journal of Management Studies, 43(4), 683-709. https://doi.org/10.1111/j.1467-6486.2006.00607.x

Cornelissen, J. P., Holt, R., \& Zundel, M. (2011). The Role of Analogy and Metaphor in the Framing and Legitimization of Strategic Change, Organization Studies, 32(12), 1701-1716. https://doi.org/10.1177/0170840611425729

Dönmez, Ö. (2008). The Management Metaphors Used in Turkish Education System (Kayseri Province Case). Unpublished Master's Thesis, Erciyes University.

Döş, İ. (2010). Metaphor perceptions of candidate teachers about the concept of inspectorate. Gaziantep University Journal of Social Sciences, 9(3), 607-629.

DPT., Eighth Five-Year Development Plan Globalization Specialization Commission Report, p.4-6.75-76, DPT Publications, Ankara, 2000.

Ekici, G. (2016). Determination of Perceptions of Biology Teacher Candidates on Microscope Concept: A Metaphor Analysis Study. Ahi Evran University Kirşehir Faculty of Education Journal (KEFAD) 17(1), 615-636.

Ekici, G., Gökmen, A., \& Kurt, H. (2014). Determination of the cognitive structures of prospetive teachers about computer concept. Gazi University Gazi Faculty of Education Journal (GEFAD), 34(3), 359-405.

Eren, E. (2008). Management and Organization, Ankara: Beta.

Erkal, M. E., Güven, Ö., \& Ayan, D. (1998). Sociological Angle of Sports, Istanbul: Der Publications.

Eruzun, C, Kınalı, Y., \& Erturan, Ö. E. (2017). A Qualitative View Into the Employment Problems of Sports Management Graduates in Turkey. Journal of International Recreation and Sport Sciences, 1(1), 13-21. Retrieved from http://dergipark.gov.tr/ijrss/issue/32895/363851

Fahey, L., \& Randall, R. (1994). The Portable Mba in Strategy. Newyork: J. Wiley İnc.

Inbar, D. (1996). The free educational prison: Metaphors and images. Educational Research, 38(1), 77-92. https://doi.org/10.1080/0013188960380106

Kösterelioğlu, M. (2014). Metaphorical perceptions of candidate teachers about the concept of school administrator. Zeitschrift für die Welt der Türken. 6(3). Taken from http://www.dieweltdertuerken.org/

Kurt, M. (1997). Arenada Show. The Past and Present of Modern Sport. İstanbul: Sorun.

Kurtipek, S., Çelik, O. B., Gümüş, H., \& Yılmaz, B. (2017). Metaphorical perceptions of camp leaders working under the ministry of youth and sports on the concept of youth. Ovidius University Annals, Series Physical Education and Sport/Science, Movement and Health, 17(2), 359-368.

https://go.galegroup.com/ps/i.do?p=AONE\&sw=w\&u=googlescholar\&v=2.1\&it=r\&id=GALE\%7CA512868484\& sid=classroomWidget $\&$ asid $=$ fe $2365 \mathrm{c} 7$

Melão, N., \& Pidd, M. (2000). A conceptual framework for understanding business processes and business process modelling. Information systems journal, 10(2), 105-129. https://doi.org/10.1046/j.1365-2575.2000.00075.x 
Miles, M. B., \& Huberman, A. M. (1994). Qualitative data analysis: An expanded sourcebook. Sage.

Miller, K. (2008). Organizational communication: Approaches and processes (5th Ed.). Belmont, CA: Thomson Wadsworth.

Monroe, C. E. (2003). An analysis of principalship metaphors at the beginning of the new millennium. (Unpublished master thesis). Faculty of the Graduate School, The University of North Carolina, Greensboro.

Öztel, H., \& Hinz, O. (2001). Changing Organizations with Metaphors. The Learning Organization, 8(4), 153-168. https://doi.org/10.1108/09696470110397602

Patton, M. Q. (2014). Qualitative Research and Evaluation Methods. Translation from 3rd Edition. (Trans. Edit.;Bütün, M \& Demir, S. B.). Ankara. Pagem Akademi.

Saban, A. (2008). School metaphors. Educational Management in Theory and Practice, 55, 459-496.

Saban, A. (2009). The mental images of prospective teachers about student concept. Turkish Educational Sciences Journal, 7(2), 281-326.

Tamimi, Y. (2005). Analysis of Organizational Culture with Metaphors (An Example of A Business Operating In the Textile Sector), Unpublished Master's Thesis, Osmangazi University, Institute of Social Sciences, Eskişehir.

Taş, A. (2016). Analysis of the relationship between entrepreneurship education and entrepreneurship tendency with parametric techniques: The Case of Abant İzzet Baysal University. Master Thesis. Abant İzzet Baysal University Institute of Social Sciences Department of Business Numerical Methods Science- Branch, Bolu.

Uzun, Z., \& Erdem, S. (2017). Investigation of Employees' Metaphoric Perceptions of Good Managers and Bad Managers: A Research in Public Institutions. Academic Overview International Refereed Social Sciences Journal, (61), 274-294.

Üzüm, H., Sönmezoğlu, U., Karlı, Ü., \& Yıldız, K. (2015). Examination of the level of influence of the employees of the sports organization from the rumors in terms of corporate communication. Atatürk University Physical Education and Sports Sciences Journal, 17(4), 37-49.

Van Eijnatten, F. M. (2004). Chaordic systems thinking: Some suggestions for a complexity framework to inform a learning organization. The Learning Organization, 11(6), 430-449. https://doi.org/10.1108/09696470410548791

Yetim, A. A. (2005). Sociology and Sports, Ankara: Morpa.

Yıldırım, A., \& Şimşek, H. (2014). Qualitative research methods in the social sciences (Extended 9th Edition). Ankara: Seçkin Publications.

Yildız, K. (2016). Sports and communication with information and communication technologies. Ankara: Nobel Publications.

Yurdakul, Y. (2015). The effect of goal setting on listening comprehension. Master Thesis. Akdeniz University, Institute of Educational Sciences, Department of Primary Education, Antalya.

\section{Copyrights}

Copyright for this article is retained by the author(s), with first publication rights granted to the journal.

This is an open-access article distributed under the terms and conditions of the Creative Commons Attribution license which permits unrestricted use, distribution, and reproduction in any medium, provided the original work is properly cited. 